\title{
Diversity of marine plankton in coral reef ecosystems at Gosong Island, Southwest Aceh
}

\author{
Nurul Najmi ${ }^{1}$, Mai Suriani ${ }^{2}$, Mira $\mathrm{M} \mathrm{Rahmi}^{1}$, and Ananingtyas S Darmarini ${ }^{1 *}$ \\ ${ }^{1}$ Department of Aquatic Resources, Faculty of Fisheries and Marine Science, Teuku Umar University, Jl. Alue Peunyareng, \\ Meulaboh 23681, West Aceh, Indonesia. \\ ${ }^{2}$ Department of Marine Science, Faculty of Fisheries and Marine Science Teuku Umar University, Jl. Alue Peunyareng, Meulaboh \\ 23681, West Aceh, Indonesia
}

\begin{abstract}
Plankton is a fundamental part of the waters, especially in coral reef ecosystems. This study aims to determine the abundance and diversity of plankton species, both phytoplankton, and zooplankton in the waters of Gosong Island, Southwest Aceh. This research was conducted in May 2021. Samples of plankton were collected from 4 sampling points with 4 replications. Phytoplankton consists of 51 species which are in 3 families, namely Cyanophyceae, Bacillariophyceae, and Dinophyceae. There are 17 species of zooplankton consisting of 7 families, namely Protozoa, Crustaceans, Urochordata, Polychaeta, Gastropods, Pelecypods, and Nematodes. The total abundance of phytoplankton ranged from 292,826 to 2,661,738 cells $/ \mathrm{m}^{3}$, while the total abundance of zooplankton ranged from 4,957 to $32,870 \mathrm{ind} / \mathrm{m}^{3}$. The composition of the presence found at the study site was found to be higher in Cyanophyceae than Bacillariophyceae and the lowest number was found in Dinophyceae. Zooplankton is found in large to low numbers in the Crustacea, Protozoa, Urochordata, Gastropod, Pelecypoda, Polychaeta, and Nematoda. This research is able to provide an initial description of diversity, abundance, and several biological indices for follow-up research. Gosong Island is an island that has coral reefs, so it is necessary to carry out routine monitoring related to the type and abundance of plankton regularly.
\end{abstract}

\section{Introduction}

Plankton is the base of marine food webs [1,2] and is a staple food source in coral reef ecosystems [1, 3]. In addition, the abundance of plankton has an important role in the trophodynamics and metabolism of reefs [4]. This role is very important for the sustainability of fisheries and marine life [2]. Waters rich in resources have a high fertility rate. This can be seen from the productivity of the waters, including the abundance and diversity of plankton [5].

The role of phytoplankton is very important because it carries out the process of photosynthesis to produce oxygen in the waters $[6,7]$. Phytoplankton biodiversity is very important for ecosystem stability and marine biogeochemistry [8], they are involved in trophic and biogeochemical dynamic and recruitment processes [3]. Phytoplankton grazing is an important component in benthic-pelagic connections on coral reefs [9]. In addition, phytoplankton is also a biological carbon pump, this is the physiological walk-on-part of phytoplankton and community structure [10]. The major concern is that phytoplankton is the basis of marine food webs and a fundamental food source in coral reef ecosystems [1].

In addition to phytoplankton, zooplankton also plays a role in coral reef ecosystems. Its important assignment is as part of the dynamic trophic [11]. According to [12] zooplankton has a close relationship with coral reef food webs and is a source of food for corals. Even [13] stated that most of the zooplankton live on coral reefs. As a food source, zooplankton is consumed by corals as they pass through coral reefs $[14,11]$.

Gosong Island is located in Susoh District, Southwest Aceh Regency, and is one part of the KKPD (Regional Water Conservation Area) of Southwest Aceh. Southwest Aceh Regency was declared a regional waters conservation area through the Aceh Governor's Decree Number 523/1297/2018 in the form of Water Nature Reserve (SAP). Based on Government Regulation No. 60 of 2007, Water Nature Reserve is a water conservation area with certain characteristics to protect the diversity of fish species and their ecosystems. As a marine conservation area, Gosong Island has a large coral reef ecosystem potential that can be found almost around the island.

The waters of Southeast Asia have very diverse habitats, including coral reefs, so that research on the abundance and composition of zooplankton is very likely to be carried out for extensive studies [15]. In addition, little is known about the diversity of plankton in the water column around coral reefs [16]. This reason strengthens the initial studies related to plankton in this area. Research about the diversity, abundance, and composition of plankton on Gosong Island has never been done before. Therefore, it is necessary to conduct

*Corresponding author: ananingtyas.s@gmail.com 
preliminary research on the diversity of marine plankton on Gosong Island, Southwest Aceh.

\section{Material and Methods}

\subsection{Study area}

Samples were collected from four stations (Figure 1) on Gosong Island, Southwest Aceh. Station 1 (St 1) was located in 096 $49^{\prime} 39.2^{\prime \prime} \mathrm{E}$ and $03^{\circ} 41^{\prime} 48.5^{\prime \prime} \mathrm{N}$, station 2 (St 2) in 096 49'29.33"E and 03'41'52.87"N, station 3 (St 3) 096 $49^{\prime} 37.3^{\prime \prime} \mathrm{E}$ and $03^{\circ} 41^{\prime} 45.5^{\prime \prime} \mathrm{N}$, and station 4 (St 4) were situated in 096 ${ }^{\circ} 49^{\prime} 33.09^{\prime \prime} \mathrm{E}$ and 03²'54.91" $\mathrm{N}$.

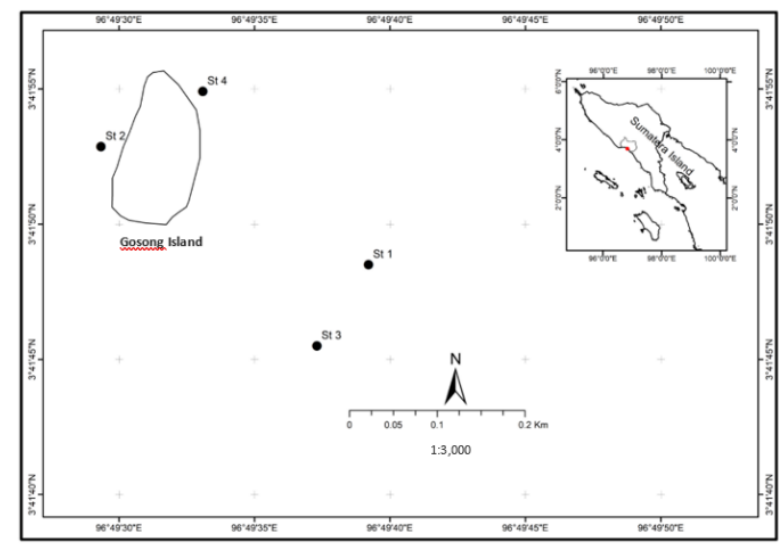

Fig. 1. Sampling station in Gosong Island, Southwest Aceh

\subsection{Plankton sampling and identification}

The sample was collected in May 2021. Plankton collection is carried out once at each station with four replications. One hundred litters of seawater from each station were filtered by using a plankton net with a 30 $\mu \mathrm{m}$ mesh size. Samples were preserved in a $100 \mathrm{ml}$ plastic bottle by $1 \mathrm{ml}$ of Lugol. $1 \mathrm{ml}$ of preserved samples was used for identification and counting on a Sedgwick Rafter Counting using a binocular microscope Nikon Eclipse 100. The species were identified in Aquatic Productivity Laboratory, Department of Aquatic Resources, Faculty of Fisheries and Marine Science, Teuku Umar University. Identification of plankton based on [17]. An abundance of plankton refers to [18]. The diversity index (H') and evenness (E) of marine plankton in Gosong Island were determined based on the Shannon-Weaner Index and the dominance (D) index was approach with Simpson's index.

\section{Result and Discussion}

\subsection{Plankton Compossition}

The results of the analysis showed that the study site had 51 phytoplankton species consisting of 3 classes, namely Cyanophyceae (2 species), Bacillariophyceae (38 species), and Dinophyceae (11 species) (Table 1). The three classes found in the research location are lower than the studies conducted in the eastern waters of Aceh, namely 5 classes with 56 species [19]. Of the 3 classes found at the research site, Bacillariophyceae is a class with a diverse number of species, namely 38 species. This shows that this class is abundant based on its type. While the Dinophyceae and Cyanophyceae classes appear less.

Based on the type, there were 19 species found at all stations, namely: Trichodesmium sp., Amphora sp., Asterionella sp., Bacillaria sp., Bacteriastrum sp., Biddulphia sp., Campylodiscus sp., Chaetoceros sp., Climacosphenia sp., Coscinodiscus sp., Fragilaria sp., Licmophora sp., Navicula sp., Nitzschia sp., Rhabdonema sp., Ceratium sp., Dinophysis sp., Orinthocercus sp., and Peridinium sp. On the other hand, some species were only found at one particular station, including Richelia sp., Achnanthes sp., Amphiprora sp., Asteromphalus sp., Cyclotella sp., Ditylum sp., Hyalodiscus sp., Lauderia sp., Mostogloia sp., Skeletonema sp., Gymnodinium sp., Gonyodoma sp., and Pyrocystis sp.

Table 1. Phytoplankton diversity in Gosong Island, Southwest, Aceh

\begin{tabular}{|c|c|c|c|c|c|}
\hline No & Genus/Station & 1 & 2 & 3 & 4 \\
\hline \multicolumn{6}{|c|}{ CYANOPHYCEAE } \\
\hline 1 & Richelia sp. & + & - & - & - \\
\hline 2 & Trichodesmium sp. & + & + & + & + \\
\hline \multicolumn{6}{|c|}{ BACILLARIOPHYCEAE } \\
\hline 3 & Achnanthes sp. & - & - & + & - \\
\hline 4 & Amphiprora sp. & - & + & - & - \\
\hline 5 & Amphora sp. & + & + & + & + \\
\hline 6 & Asterionella sp. & + & + & + & + \\
\hline 7 & Asterolampra sp. & - & - & + & + \\
\hline 8 & Asteromphalus sp. & - & + & - & - \\
\hline 9 & Bacillaria sp. & + & + & + & + \\
\hline 10 & Bacteriastrum sp. & + & + & + & + \\
\hline 11 & Biddulphia sp. & + & + & + & + \\
\hline 12 & Campylodiscus sp. & + & + & + & + \\
\hline 13 & Chaetoceros sp. & + & + & + & + \\
\hline 14 & Climacosphenia sp. & + & + & + & + \\
\hline 15 & Cocconeis sp. & + & + & - & + \\
\hline 16 & Coscinodiscus sp. & + & + & + & + \\
\hline 17 & Cyclotella sp. & - & - & - & + \\
\hline 18 & Diatom sp. & + & - & + & + \\
\hline 19 & Diploneis sp. & - & + & + & + \\
\hline 20 & Ditylum sp. & + & - & - & - \\
\hline 21 & Fragilaria sp. & + & + & + & + \\
\hline 22 & Hemiaulus sp. & - & - & + & + \\
\hline 23 & Hyalodiscus sp. & - & - & - & + \\
\hline 24 & Lauderia $\mathrm{sp}$. & - & + & - & - \\
\hline 25 & Leptocylindrus sp. & + & + & - & - \\
\hline 26 & Licmophora sp. & + & + & + & + \\
\hline 27 & Melosira sp. & - & + & + & + \\
\hline 28 & Mostogloia sp. & - & - & - & + \\
\hline 29 & Navicula sp. & + & + & + & + \\
\hline 30 & Nitzschia sp. & + & + & + & + \\
\hline 31 & Pinnularia sp. & + & + & - & - \\
\hline 32 & Pleurosigma sp. & - & + & + & + \\
\hline 33 & Podocystis sp. & - & + & - & + \\
\hline
\end{tabular}




\begin{tabular}{|c|c|c|c|c|c|}
\hline 34 & Rhabdonema $\mathrm{sp}$. & + & + & + & + \\
\hline 35 & Rhizosolenia $\mathrm{sp}$. & + & + & - & + \\
\hline 36 & Skeletonema $\mathrm{sp}$. & + & - & - & - \\
\hline 37 & Surirella $\mathrm{sp}$. & - & + & + & + \\
\hline 38 & Thalassionema $\mathrm{sp}$. & - & + & - & + \\
\hline 39 & Thalassiothrix $\mathrm{sp}$. & + & + & + & - \\
\hline 40 & Triceratium $\mathrm{sp}$. & + & + & + & + \\
\hline \multicolumn{7}{|c|}{ DINOPHYCEAE } \\
\hline 41 & \multicolumn{7}{|c|}{ Ceratium $\mathrm{sp}}$. & + & + & + & + \\
\hline 42 & Dinophysis $\mathrm{sp}$. & + & + & + & + \\
\hline 43 & Diplopsalis $\mathrm{sp}$. & + & + & + & - \\
\hline 44 & Gymnodinium $\mathrm{sp}$. & - & + & - & - \\
\hline 45 & Gonyodoma $\mathrm{sp}$. & + & - & - & - \\
\hline 46 & Orinthocercus $\mathrm{sp}$. & + & + & + & + \\
\hline 47 & Peridinium $\mathrm{sp}$. & + & + & + & + \\
\hline 48 & Podolampas $\mathrm{sp}$. & - & + & + & + \\
\hline 49 & Prorocentrum sp. & + & + & + & - \\
\hline 50 & Pyrophacus $\mathrm{sp}$. & + & + & - & - \\
\hline 51 & Pyrocystis $\mathrm{sp}$. & - & + & - & - \\
\hline
\end{tabular}

Cyanophyceae class is a type of class that is only composed of 2 species and one of them is found in all stations, namely Trichodesmium sp., although the number of species in the research location is only a few, it needs attention. Trichodesmium sp. including Cyanobacteria species based on [20] have a role in photosynthesis and nitrogen fixation in lakes and seas. In addition, the genus Trichodesmium is a major source of marine nitrogen and the nitrogen cycle [21] but has the potential to cause blooms [20].

Bacillariophyceae (Diatom) is the class with the highest number of species found in the study area. Several studies have shown that this class is indeed found with various species in marine [22,23], has an important ecological role [21], and contributes remarkably to total global primary $[24,25]$. The most common species found from several reports illustrate that this species is dominantly found $[26,27]$. The result of the new research the phytoplankton diversity of this community is influenced by geographical factors that do not depend on environmental conditions [28].

The types of zooplankton found in Gosong Island were 26 species consisting of 7 Groups, namely Protozoa (11 species), Crustacea (10 species), Urochordata, Gastropods, Pelecypoda, Polychaeta, and Nematoda 1 species each (Table 2). The number of species found in the study area was less than the results of research in aquaculture areas [29] and seagrass habitats [30]. Table 2 shows some types of zooplankton found at all stations are Stenosemella sp., Nauplius (stadia), Oithona sp., and Paracalanus sp.. Some types of zooplankton are also found only at certain stations including Didinium sp., Favella sp., Leprotintinnus sp., Protorha bdonella sp., Corycaeus sp., Temora sp. Larva Pelecypoda, Larva Polychaeta, and Nematoda.

Several types of zooplankton from the Protozoa group found at the research site can be key species in an ecosystem. This is in line with the opinion [31] which states that Stenosemella nivalis, $S$. ventricosa, and Tintinnopsis sp. are key species in the Northern
Adriatic Sea and the loss of this species is a sign of structural changes in the planktonic system.

Table 2. Zooplankton diversity in Gosong Island Southwest, Aceh.

\begin{tabular}{|c|c|c|c|c|c|}
\hline No & Genus/Station & $\mathrm{I}$ & II & III & IV \\
\hline \multicolumn{6}{|c|}{ PROTOZOA } \\
\hline 1 & Codonellopsis sp. & + & + & - & + \\
\hline 2 & Didinium sp. & + & - & - & - \\
\hline 3 & Favella sp. & + & - & - & - \\
\hline 4 & Globigerinoides sp. & - & - & - & + \\
\hline 5 & Globorotalia sp. & - & + & + & + \\
\hline 6 & Leprotintinnus sp. & - & + & - & - \\
\hline 7 & Pleurspis sp. & + & + & - & - \\
\hline 8 & Protorhabdonella sp. & + & - & - & - \\
\hline 9 & Rhabdonella sp. & + & + & - & - \\
\hline 10 & Stenosemella sp. & + & + & + & + \\
\hline 11 & Tintinnopsis sp. & + & + & + & - \\
\hline \multicolumn{6}{|c|}{ CRUSTACEAE } \\
\hline 12 & Acrocalanus sp. & + & + & - & - \\
\hline 13 & Corycaeus sp. & - & + & - & - \\
\hline 14 & Euterpina sp. & + & - & + & + \\
\hline 15 & Microsetella sp. & + & + & - & + \\
\hline 16 & Nauplius (stadia) & + & + & + & + \\
\hline 17 & Oithona sp. & + & + & + & + \\
\hline 18 & Oncaea sp. & + & + & - & - \\
\hline 19 & Paracalanus sp. & + & + & + & + \\
\hline 20 & Temora sp. & - & + & - & - \\
\hline 21 & Tigriopus sp. & - & - & + & + \\
\hline \multicolumn{6}{|c|}{ UROCHORDATA } \\
\hline 22 & Oikopleura sp. & + & + & - & - \\
\hline \multicolumn{6}{|c|}{ GASTROPODA } \\
\hline 23 & $\begin{array}{l}\text { Larva Gastropoda } \\
\text { (sp1) }\end{array}$ & + & + & - & + \\
\hline \multicolumn{6}{|c|}{ PELECYPODA } \\
\hline 24 & $\begin{array}{l}\text { Larva Pelecypoda } \\
\text { (sp1) }\end{array}$ & + & - & - & - \\
\hline \multicolumn{6}{|c|}{ POLYCHAETA } \\
\hline 25 & $\begin{array}{l}\text { Larva Polychaeta } \\
\text { (sp1) }\end{array}$ & - & + & - & - \\
\hline \multicolumn{6}{|c|}{ NEMATODA } \\
\hline 26 & Nematoda (sp1) & - & - & - & + \\
\hline
\end{tabular}

\subsection{Abundance and Structure Community}

The results of the analysis of community structure (Table 3) show conditions of abundance, diversity index, uniformity, and dominance in the waters around Gosong Island. The highest abundance of phytoplankton was found at station IV, which was 2661738 cells $/ \mathrm{m}^{3}$. The highest abundance by species at the study site was Cyanophyceae: Trichodesmium sp.

(1436706.5 cell $\left./ \mathrm{m}^{3}\right)$, Bacillariophyceae: Rhabdonema sp. (101217.3 cell $\left./ \mathrm{m}^{3}\right)$, Chaetoceros $\mathrm{sp}$. (18510.74 cell $\left./ \mathrm{m}^{3}\right)$, and Nitzchia $\mathrm{sp.} \quad\left(17888.6 \quad\right.$ cells $\left./ \mathrm{m}^{3}\right)$, Biddulphia $\mathrm{sp}$. (9152.2 cell $\left./ \mathrm{m}^{3}\right)$, Licmophora $\mathrm{sp}$. $\left(8413.1 \mathrm{cell} / \mathrm{m}^{3}\right)$ and Dinophyceae: Ceratium sp. (13554.2 cell $\left./ \mathrm{m}^{3}\right)$ and, 
and Peridinium sp. $\left(5489.1\right.$ cells $\left./ \mathrm{m}^{3}\right)$. Forty-three other species have lower abundances. High abundance of Trichodesmium sp. presumably because the time of sampling is approaching the transition season so that its presence dominates. This condition is reinforced by the opinion of [32] which states that the abundance and distributionof Trichodesmium thiebautii and Trichodesmium eryhtraeum dominates the transition season. In addition, the abundance of phytoplankton is also influenced by the availability of nutrients, and nitrate enrichment can have an impact on the growth potential and large biomass accumulation [33].

Rhabdonema sp. is the second most abundant species, including the Tablelariaceae family of the Bacilliaophyceae class. This species is an epilithic diatom, apart from this type, there are also other epilithic diatoms with high waste, namely Licmophora sp. Both can be found abundantly in shallow areas or deep sites [34]. Other species found in abundance were Biddulphia sp., and Chaetoceros sp. this species is often found in abundance in several locations [35, 19]. The abundance, Diversity, Evenness, and Dominance index of Plankton in Gosong Island is presented in Table 3. Phytoplankton have an average diversity index is 1.03, the evenness index is 0.33 and the dominance index is 0.64 . This value description shows an indication of the dominance of the presence of certain species. The diversity index at the study site is higher when compared to the Gerupuk Bay area, West Nusa Tenggara, Indonesia [35].

The highest abundance of zooplankton reached a value of $32.870 \mathrm{ind} / \mathrm{m} 3$ with an average diversity index of 1.4, evenness 0.64 , and dominance 0.48 . Zooplankton abundance was higher than zooplankton abundance in Lawas seagrass habitat, Sarawak, Malaysia [30]. However, it is lower than research in East Yapen Papisir water, Papua [36], Gulf of Aqaba, and Northern Red Sea [37]. The abundance and distribution of zooplankton are strongly influenced by currents [38]. The zooplankton diversity index on Gosong Island is lower than the 2018 study by [34] which reached 3.35 and [39], which reached 2.4-2.6. The index of uniformity and dominance of the zooplankton community describes a fairly good condition.

The relationship between phytoplankton and zooplankton is seen descriptively based on the results of the analysis, so there is a relationship between the presence of phytoplankton and zooplankton at each station. The linkage relationship is illustrated by if the number of phytoplankton is low, the zooplankton is also low. This shows that the abundance of zooplankton is influenced by the abundance of phytoplankton. In addition, the low number of zooplankton species can be caused by a lack of food sources in the waters. The adaptation made by zooplankton when there is a shortage of food is to look for other food alternatives. For example, Copepoda mentioned will consume terrigenous detritus as an additional food source when the number of phytoplankton is limited [40].

Table 3. Abundance, Diversity, Evenness and Dominance index of Plankton in Gosong Island Southwest, Aceh.

\begin{tabular}{|c|c|c|c|c|c|}
\hline St & Plankton & Abundance & $\begin{array}{c}\text { Diversity } \\
\left(\mathrm{H}^{\prime}\right)\end{array}$ & $\begin{array}{c}\text { Evennes } \\
\text { S (E) }\end{array}$ & $\begin{array}{c}\text { Dominance } \\
\text { (C) }\end{array}$ \\
\hline I & \multirow{4}{*}{$\begin{array}{l}\text { Phytoplankton } \\
\left(\mathrm{sel} / \mathrm{m}^{3}\right)\end{array}$} & 2545782 & 0.53 & 0.18 & 0.82 \\
\hline II & & 1052172 & 1.32 & 0.41 & 0.55 \\
\hline III & & 292826 & 1.50 & 0.50 & 0.45 \\
\hline IV & & 2661738 & 0.75 & 0.23 & 0.74 \\
\hline I & \multirow{4}{*}{$\begin{array}{l}\text { Zooplankton } \\
\left(\text { ind } / \mathrm{m}^{3}\right)\end{array}$} & 29,544 & 1.39 & 0.63 & 0.40 \\
\hline II & & 16,695 & 1.36 & 0.66 & 0.44 \\
\hline III & & 4,957 & 0.93 & 0.80 & 0.48 \\
\hline IV & & 32,870 & 0.87 & 0.48 & 0.59 \\
\hline
\end{tabular}

The composition of the presence of plankton is presented in figures $2 \mathrm{a}$ and $\mathrm{b}$. Figure $2 \mathrm{a}$ illustrates that the abundance of phytoplankton in the Cyanophyceae class is higher than that of Bacillariophyceae and Dinophyceae. This composition is different from some published research results, such as the results of research by [41] in the Bali Strait, it was found that the composition of Bacillariophyceae offshore reached $85 \%$ and nearshore reached $78 \%$. Likewise, the results of research by [19] in the coastal water of Lubuk Damar Aceh Tamiang found that the composition of Bacillariophyceae reached $85 \%$.

The percentage of the various classes sorted largest to smallest: Cyanophyceae $>$ Bacillariophyceae $>$ Dinophyceae. The most common class of phytoplankton was Cyanophyceae with $87.89 \%$ (Fig. 2a). Trichodesmium sp. from Cyanophyceae was recorded as a dominating species at each station. Phytoplankton dominance by Trichodesmium sp. need to be careful because it can cause blooms of Trichodesmium sp. which is harmful to other organisms and disturbs the balance of the ecosystem.

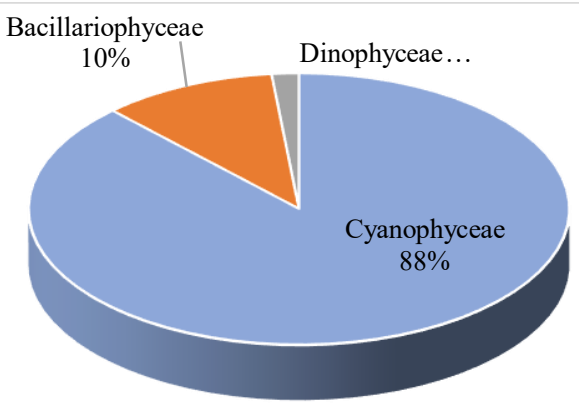

a

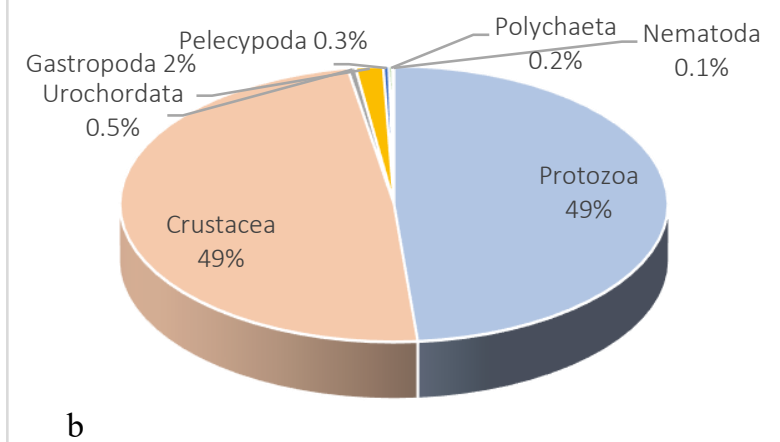

Fig. 2. Abundance of phytoplankton (a) and zooplankton (b) in Gosong Island water 
The difference in class composition at different locations is thought to be due to different environmental conditions or the availability of nutrients to support the survival of certain phytoplankton. This is in line with the opinion of [42] which states that high abundance is due to greater adaptation to the environment compared to other classes. Figure $2 \mathrm{~b}$ shows the composition of zooplankton with a balanced composition of Crustaceans and Protozoa while other species are less than 2\%. The large composition of Crustacea and Protozoa classes is caused by the abundance of Nauplius (stadia) and Codonellopsis sp. Zooplankton composition comprised Crustacea $>$ Protozoa $>$ Urochordata $>$ Gastropoda $>$ Pelecypoda $>$ Polychaeta $>$ Nematoda. The most common groups found were Crustacea (48.67\%) and Protozoa (48.62\%). [43] said that overall, crustaceans dominate marine zooplankton. The abundance of crustacean groups is due to the species constituting crustaceans having a wide distribution of species because they can adapt to extreme environmental conditions [44]. The large abundance of crustacean species in the study area is the same as the results of research in Est Yapen Papisir water, Papua [36].

The different composition of each type of plankton is influenced by several factors, including the availability of food sources and environmental conditions. Because the availability of resources, in this case, is nutrition will explain the variation in biomass, productivity, and species richness, this is because each species has a monopoly on the availability of resources in the food web and the environment in this case is food quality and toxicity [45]. The composition of plankton species formed according to [46] plays a key role in the ongoing functioning of the ecosystem. This is due to the ecological and biological differences of phytoplankton characteristics that can be used as an assessment of ecosystem conditions [1]. Protecting the ecosystem is due to the dynamic and trophic relationship between different groups in this case phytoplanktonzooplankton-fish [47].

\section{Conclusion}

Phytoplankton composition consists of Cyanophyceae, Bacillariophyceae, and Dinophyceae. The most common class of phytoplankton was Cyanophyceae with $88 \%$. Trichodesmium sp. was dominant at each station. Zooplankton consists of Crustacea, Protozoa, Urochordata, Gastropods, Pelecypoda, Polychaeta, and Nematoda. The most common groups of zooplankton found were Crustacea and Protozoa. The abundance of phytoplankton was higher than Zooplankton. The results of the study of marine plankton in the waters of Gosong Island which is a very important coral reef area because it is a food source. The abundance of phytoplankton in the study area will support the existence of zooplankton. Both can support the sustainability of coral in the area. So that it becomes a dynamic relationship between phytoplankton-zooplankton-coral reef. This initial research is the basis for conducting a more in-depth study of the relationship between the diversity of plankton species and the coral reef communities.

Acknowledgments. The author is to express for Pusong Diving Club (PDC) for its excellent facilities and to thank the anonymous reviewers for the worthwhile comments on the manuscript. The authors expresses gratitude to the Institute for Research and Community Service (LPPM) of Teuku Umar University which has funded research through an internal grant scheme. In addition, the authors also thank the Faculty of Fisheries and Marine Science, Teuku Umar University which has supported research and publication activities.

\section{References}

1. M. Racault, D.E. Raitsos, M.L. Berumen, R.J.W. Brewin, T. Platt, S. Sathyendranath, I. Hoteit, Remote Sensing of Environment, 160, 222-234 (2015)

2. S.D. Batten, R. Abu-Alhaija, S. Chiba, M. Edwards, G. Graham, R. Jythibabu, J.A. Kitchener, P. Koubbi, A. McQuatters-Gollop, E. Muxagata, C. ostle, A.J. Richardson, K.V. Robinson, K.T. Takahashi, H.M. Verheye, W. Wilson, frontiers in Marine Science, 6 (2019)

3. A. Carrillo-Baltodano, A. Morales-Ramirez, Revista de Biología Tropical, 64, 3 (2016)

4. Y.I. Sorokin, Plankton in Coral-Reef Waters. In: Coral Reef Ecology. Ecological Studies (Analysis and Synthesis). Springer Berlin (1995)

5. J.W. Nybakken, Biologi Laut suatu pendekatan ekologis. (Jakarta 1992)

6. F. Not, R. Siano, W.H.C.F. Kooistra, N. Simon, D. Vaulot, I. Probert, Advances in Botanical Research, 64 (2012)

7. F.J. Vincent, S. Colin, E. Scalco, L. Bitter, Y. Garcia, R.M.M. Lopes, J.R. Dolan, A. Zingone, C. de Vargas, C. Bowler, The ISME Journal, 12,10941108 (2018)

8. S. Dutkiewicz, P. Cermeno, O. Jahn, M.J. Follows, A.E. Hickman, D.A.A. Taniguchi, B.A. Ward, Biogeosciences, 17, 609-634 (2020)

9. G. Yahel, A.F. Post, K. Fabricius, D. Marie, D. Vaulot, A. Genin, Limnol. Oceanogr, 43, 4 (1998)

10. S. Basu, K.R.M. Mackey, Sustainability, 10, 869 (2018)

11. Heidelberg KB, O’Neil K.L, Bythell J C, Sebens KP. Journal of Plankton Research. 32, 1 (2010)

12. O. Esqual-Garrote, A. Morales-Ramirez, Revista de Biologia Tropical 68 (suppl. 1) S261-S270 (2020)

13. A.L. Alldredge, J.M. King, Marine Biology, 41 (1977)

14. Hammer WM, Colin PL, Hamner PP. Marine Ecology Progress Series. 334, 83-92

15. S. Nishida, N. Miyazaki, in Nishida S, Fortes MD, Miyazaki $\mathrm{N}$ eds. Coastal Marine Science in Southeast Asia-Synthesis Report of the Core University Program of the Japan. Society for the Promotion of Science: Coastal Marine Science (2001-2010) (2011)

16. J.K. Pearman, M.M. El-Sherbiny, A. Lanzen, A.M. Al Aidaroos, X. Irigoien, Frontiers in Marine Science 1, 27 (2014) Congress on Advances in 
Nuclear Power Plants, ICAPP, 2-5 May 2011, Nice, France (2011)

17. I. Yamaji, Illustration of the Marine Plankton of Japan Hoikusha Publishing Co. Ltd. Japan (1979)

18. E.W. Rice, R.B. Baird, A.D. Eaton, L.S. Clesceri, APHA: Standart Method for The Examination of Water and Wastewater 22th ed. AWWA (American Water Works Association) and WEF (water Environment Federation). Washington DC (US) (2012)

19. A.S. Darmarini, Y. Wardiatno, T. Prartono, K. Soewardi, D. Ardania, IOP Conf. Series, 674, 012023 (2021)

20. B.A. Whitton, M. Potts, Ecology of Cyanobacteria II: Their Diversity in Space and time (Springer Science (2007)

21. L. Hoffman, Eur. J. Phycol, 34: 371-379 (1999)

22. S. Malvia, E. Scalco, S. Audic, F. Vincent, A. Veluchamy, J. Poulain, P. Wincker, D. Iudicine, C. de Vargas, L. Bitter, A. Zingone, C. Bowler, PNAS, 29 (2016)

23. X. Lu, Y. Liu, Y. Fan, Water, 12 (2020)

24. A. Yool, T. Tyrell, Global Biogeochemical Cycles, 17, $4(2002)$

25. S. Licea, J.L. Moreno-Ruiz, R.J. Luna, Biodivers Endanger Species, 4,174 (2016)

26. D.Y. Wulandari, N.T.M. Pratiwi, E.M. Adiwilaga, Jurnal Ilmu Pertanian Indonesia, 19, 3 (2014)

27. H. Wiyarsih, Endrawati, S. Sedjati, Buletin Oseanografi Marina, 8, 1 (2019)

28. P. Vanormelingan, E. Verleyen, W. Vyverman, Biodiversity and Conservation, 17, 2 (2009)

29. O.Z. Ahmad, H. Endrawati, N. Taufiq, Journal of Marine Research, 3, 3 (2014)

30. J. Ismail, A.H.M. Kamal, M.H. Idris, S.M.N. Amin, H. Hamli, L.S. Sien, A. Al-Asil, M.H. Abualreesh, Biodiversity Data Journal, 9, e67449 (2021)

31. M. Monti-Birkenmeier, T. Diociaitui, S.F. Umani, Nature Conservation, 34, (2019)

32. A. Sediadi, Makara Sains, 8, 1 (2004)

33. R.M. Kudela, Dugdale, Deep-Sea Research Part II: Topical Studies Oceanography, 47, 5-6 (2000)

34. D. Hafner, A. Car, N. Jasprica, T. Kapetanovic, I.D. Radic, Medit Mar. Sci, 19, 2 (2018)

35. Purnamaningtyas SE., Mujiyanto, and Riswanto. Jurnal Akuatika Indonesia 4, 1 (2019)

36. K. Paiki, J.D. Kalor, E. Indrayani, L. Dimara, Maspari Journal, 10, 2 (2018)

37. Mantha G, Al-Sofyani A.A, M. Ali A, Crosby M.P. Acta Oceanologica Sinica. 38, 59-72 (2019)

38. R.A. Morales, M.M. Murillo, Rev. Biol. Trop, 44, 2 (1996)

39. I. Noventalia, H. Endrawati, M. Zainuri, Journal of Marine research, 1(1):19-23 (2012)

40. S. Hu, Z. Guo, C. Xu, H. Huang, S. Liu, J. Lin. Plankton Res, 37, 2 (2015)

41. N.T.M Pratiwi, D.Y. Wulandari, I.P. Ayu, A. Iswantari, IOP Conf. Series: Earth and Environmental Science, 54, 012090 (2020)

42. E.P. Odum, Fundamental of Ecology. Philadelphia: Ed. W.B. Saunders (1971)

43. J.W. Nybakken, M.D. Bertness, Marine Biology Pearson/Benjamin Cummings Science (2005)
44. K. Romimohtarto, S. Juwana, Biota Laut: Ilmu Pengetahuan Tentang Biota Laut, Jakarta (2004)

45. S. Lehtinen, T. Tamminen, R. Ptacnik, T. Andersen, Lomnol. Oceanogr, 62:1393-1408 (2017)

46. J. Otero, X.A. Alvarez-Salgado, A. Bode, Front. Mar. Sci. (2020)

47. S. Lomartire, J.C. Marques, A.M.M. Goncalves, Ecological Indicator, 129, 11:107867 (2021) 